Article

\title{
From Brokenness of Death to Refigured Forgiveness: Reflections on Ricoeur's Fault, Narrativity, and Capable Human Being
}

Jonathan Ray Villacorta

\author{
For Amiel \\ . . . whose life healed our brokenness; \\ . . . whose story capacitates us to forgive; \\ . . . whose memory makes us hope for infinity.
}

\section{Introduction: From Brokenness to Possibility}

A $\mathrm{s}$ if doused with a bucket of cold water, ${ }^{1}$ the realization of man's brokenness comes to him not in the gentle humming of a summer reflection and offer him, whether he likes it or not, the opportunity to see his seemingly united life for what it really is: incomplete, unnarrated, unreflected. The realization that one's life is a painful tension between the finite and infinite, between necessity and freedom, comprises the existential presence of nagging disproportion and irrecusable faultedness. The tension is there and the fault is real and non-fortuitous. ${ }^{2}$

The easiness of the preceding statements losses their playful tone when the reflection will have to deal with the painful reality of death. Indeed, death, even the ones that some people are prepared for, comes with painful blows in the hearts of loved ones left behind. One, then, can only imagine the great pangs of pain that pierce the hearts of the bereaved upon hearing a young life that has been ended abruptly by series of uncontrollable occurrences-alas! Tragedy! This particular human experience pushes man's brokenness to fore, illuminating the gap in human constitution, casting on humanity's fault a

1 This is an imagery inspired by Gabriel Marcel's "plunge under an icy shower." Gabriel Marcel, "Primary and Secondary Reflection: The Existential Fulcrum" in Philosophy of Man: Selected Readings, ed. by Manuel B. Dy, Jr. (Makati City: Goodwill Trading Co., Inc., 1986), 71.

2 Ricoeur says “. . . it is really in thinking that we break the living unity of man, but to think, in the broadest sense, it is the fundamental act of human existence and this act is the rupture of a blind harmony, the end of a dream." Freedom and Nature: The Voluntary and the Involuntary, trans. by Erazim V. Kohak (USA: Northwestern University Press, 1966), 444. 
blinding radiance which forces one to think and rethink his life and its possibilities.

This is a difficult experience, indeed. And most often, one is rendered incapacitated to act before the pain, both overwhelming and ghastly. But how can one really act before the death of a loved one? How can a mother and a father be capable of forgiveness, let alone love, before the towering desire for recompense for a life tragically lost? How can a family saddled by the heavy weight of death utter the words of unbinding to a world that seems to revel on absurdity and irrationality? These questions are difficult to answer. But one must try to respond to these questions as intelligently as one can. It is the only hope for a happy life after a tragedy. What has death broken, one has to recuperate via the long route of narration for an ethical, that is, happy life capable of forgiveness and filled with love, to ensue.

\section{Death: From Refusal to Consent}

A person's life is a series of tensions, and tremendous effort and amount of energy is exerted to reduce these tensions to small gaps that would allow a momentary sense of ephemeral unity. St. Augustine understands this, when in Book 2, Chapter 5 of his Confessions, he says that sins are committed not because we will evil but because the goods that we aspire or, even covet are goods lower than the highest good Himself. ${ }^{3}$ This painful longing for absolute unity is appeased temporarily by acquiring something finite. And yet, this peace that is gained by the person's raging heart stands on precarious grounds, waiting to be toppled, readying for a dizzying headlong crash to the indefiniteness that human existence desires to abandon. Did Augustine not already say that, "our hearts is restless until it rests in you?" 4 The fault, the break in human existence is always made more apparent in moments of heartrending experiences, experiences that reveal the primordial state of the human soul which is characterized by distention and disproportion.

Paul Ricoeur, in his Freedom and Nature: The Voluntary and the Involuntary, discusses the three sorrows of the human being that arise from the "virulent dualisms" present in the very structure of the person's existence. The dualism of body and soul, freedom and necessity, forces man to reflect on his existence, to reflect on his fragility precisely because this fragility - the fault that separates necessity and freedom-is scandalous to thought. ${ }^{5}$ Freedom and necessity

3 Augustine beautifully states that sin happens when we have immoderate liking for the goods of the earthly life, thereby abandoning the Supreme Good: "This life which we live here has its own allurements, which come from its particular mode of beauty and all its agreement with all these lower beauties. The friendship of men, bound together by a loving tie, is sweet because of the unity it fashions among many souls. With regard to all these things, and others of like nature, sins are committed when, out of a immoderate liking for them, since they are at least goods, we desert the best and highest goods, which You are, O Lord our God, and your truth and your law." Augustine, The Confessions of St. Augustine, trans. by John K. Ryan (New York: Image Book Doubleday, 1960), 71.

${ }^{4}$ Ibid., 43.

${ }^{5}$ Ricoeur, Freedom and Nature: The Voluntary and the Involuntary, 444. 
negate each other. On the one hand, necessity limits me, and my possibilities. The richness of my consciousness and imagination is tempered by my particular limitations that are inherent in my countenance. My possibilities are rich but this richness is in constant threat. Ricoeur beautifully expressed this by saying, "everything that constitutes my particularity limits me...I am borne up by what at the same time ties me down."6

Freedom, on the other hand, negates necessity with its no. It refuses to admit the limitations posited by the body and the limitations that inevitably result from the act of choosing: freedom is the act of one's withdrawal from itself. According to Ricoeur, this withdrawal could be seen in the two aspects of freedom that Descartes and Kierkegaard have graciously bequeathed us, namely, the freedom of doubt and the freedom that trembles before disproportion. ${ }^{7}$ Both aspects of freedom are the Cogito's recoil from itself: the former is the withdrawal from the limits of the body and so it hyperbolically doubts everything; the doubt itself is the very defiance of the cogito against the evil genius; and the latter is the freedom that trembles before the infinite wide space of possibility that is negated by the very finitude of the human person.

The no of freedom is continuously expressed in the three sorrows of man, namely, sorrow of finitude, formlessness, and contingence. The necessities of man render his disproportion in great resplendence, allowing him to experience the paradox of necessity and freedom in its most gruesome. The possibilities amputated by character, the uncertainty caused by the movement of the unconscious and the realization that I lack aseity comprise the veracity of human sorrow for these limitation are always negated by the infinite possibilities of freedom. ${ }^{8}$ Freedom says $n o$ to these limitations but this $n o$ has to be put in checked. Here, Ricoeur intimates the task of philosophy in the light of these three sorrows:

Philosophy for us is a meditation of the yes, and not the surly intensification of the no. Freedom does not will to be a leper, but the completion of nature in so far as it is possible in this age through, which we pass as pilgrims. ${ }^{?}$

What philosophy should do then is to overcome the negation, the paradox of necessity and freedom, as well as it can and try to restore to man the capacity to act despite his limitations and brokenness. But the question lingers, how is ethics, a happy life, possible if the experience is as brutal as the tragic death of a loved one? But before answering this question, it is good to look at Ricoeur's exposition of death and how it should be understood in view of man's disproportion.

Death for Ricoeur, unlike the three moments of necessity enumerated above, is not given to feeling. Death for Ricoeur is a negation totally foreign to

\footnotetext{
${ }^{6}$ Ibid., 445.

7 Ibid., 445-446.

${ }^{8}$ See Ricoeur's discussion of the three moments of necessities in ibid., 447-456.

${ }^{9}$ Ibid., 446.
} 
the self, a phenomenon whose necessity I learn empirically. Death, then, is not natural; it is not part of the design of life but an interruption from without:

Nothing in the inner experience of the cogito shows me my death; even my limitations are still qualification and perhaps even an exultation of my presence. Death is the end, the interruption of limitations as well as of capacities. ${ }^{10}$

But this alienation of death from the constitution of life does not exonerate a person from the pain that it brings. The strength of the death's sting is such that even if it is given to me from the outside, "it tends to appear as an original experience."11 Through the death of another man, especially that of someone I love, I am forced to face my own mortality; I am informed of my own further brokenness.

The pain caused by the death of the other makes me realize my own suffering self. "...[T] he dead is one who no longer responds-he is absent, vanished." 12 According to Ricoeur, one does not need the spectacle of the corpse or elaborate funeral rites to feel the pain of the death of the other. The unresponsiveness of the other who passed away is already enough to make one realize that the other is gone, to make him realize that death is real, that his is imminent. The silence of the other who has now passed away fills the silence of the loved ones' nights, mourning not only for the life that is gone, but more for the life that remains. Ricoeur says this beautifully: "Love suffers precisely because one is gone and the other remains: each man dies alone and each man is left alone on the shore." 13

Now the question could finally be asked: What is the possibility of happiness that is an ethical life, after the painful experience of death and the mortifying realization of our own mortality? Furthermore, in the case of a life tragically lost, how is forgiveness possible? Indeed, what path could be taken, after the realization of man's existential faultedness, which could lead us to the capable human being?

\section{From Brokenness to Narrative Refiguration}

The broken human being does not give itself to us in complete immediacy. One cannot know the self in the romantic sense of Dilthey or

${ }^{10}$ Ibid., 458.

11 Ibid., 459

12 The next few lines after this quoted statement are equally beautiful: "For this radical experience we need neither an elaborate image of agony nor the equivocal spectacle of a corpse, nor funeral rites. DDeath] spreads out in the sheer absence which is only in the heart, and it is this silence which lends gravity to the final agony which it makes a separation, which lends the corpse its desolation, lamenting its false absence, and grief to funeral rites which makes it a solemn farewell (italics mine)." Ibid., 460.

${ }^{13}$ Ibid. 
Schleiermacher, ${ }^{14}$ whose hermeneutics precisely lies on the desire to know the very intention of the author and to know the author better than the author knows himself. This romantic project, very close to the Cartesian Cogito, is not a plausible option anymore after the collapse of the idealistic project of positing an absolute ego which knows itself immediately. The philosophical corollaries of Nietzsche's suspicion, of Heidegger's Dasein and of Gadamer's Verfremdung prompted a hermeneutics that does not seek to relive the genius of the author but to look at the self that is continuously metamorphosed in front of the text. The implication of this philosophical presupposition has a tremendous impact on my reflections in this paper, since it is an attempt to look at the possibility of ethical, that is, happy life, for a faulted human being who is riddled by the painful reality of death. My claim is that an ethicalhappy life can only happen through the mediation of narrativity in life, written or spoken.

Leovino Garcia, in one of his unpublished essays "Hermeneutics: Doing Philosophy with the Social Sciences, Arts and Literature" says succinctly that "philosophy has the task-and therefore the responsibility-of safeguarding the basic openness of language, of promoting the creative power of language which implies its possible expressions into different levels." 15 This basic concern for language is permeated in the interstices of Ricoeur's hermeneutics. And rightly so, for it is only through the mediation of language that we get to understand others and ourselves: "we understand ourselves only by the long detour of the signs of humanity in cultural works." 16 This statement allows one to see that Ricoeur's hermeneutics is not only confined in

14 Although Dilthey and Schleiermacher contributed a lot in hermeneutics by giving it the status of science by providing it a general methodology that is not confined solely with exegesis of the scriptures, classical texts and jurisprudence, their hermeneutics is still confined with the desire to know immediately the author by reliving the author's genius. This methodology has already been pulverized by the three masters of suspicion (Nietzsche, Marx, and Freud) who conceived man as not capable of knowing himself directly. See Ricoeur's discussion of Schleiermacher and Dilthey in his essay, "The Task of Hermeneutics," in From Text to Action (Evanston Illinois: Northwestern University Press, 1991), 55-63.

15 The different levels of language that philosophy has to protect are ordinary language, scientific, poetic and religious. These various levels of language allow the human being to express himself in relation to the world, his fellowmen and himself in different ways. These various expressions have to be protected by philosophy so that not one expression could assume greatness over the other as if it is the only way to express the presence of man. Leovino Garcia, "Hermeneutics: Doing Philosophy with the Social Sciences, Arts and Literature," (Unpublished), 1.

16 Paul Ricoeur, "The Hermeneutical Function of Distanciation," in From Text to Action, 87. Also, see Ricoeur's Time and Narrative, where he discusses that the cultural and normative symbolisms that are already present in the lived-experiences of people enable one to comprehend that actions even in the pre-narrative stage require interpretation. These symbols, embedded in culture and convention furnish for themselves the descriptive context that one should use in interpreting an action as a meaning of this or that. This readability of action through culture and convention is what is present in cultural works, most especially in the written texts. Through the text, then, one does not only become aware of his possibilities, one also begins to understand his own culture since it is now seen as a meaning to be interpreted. Paul Ricoeur "Time and Narrative: Threefold Mimesis," in Time and Narrative, I (Chicago: University of Chicago Press, 1990), 58. 
the text and its structures. By positing Verfremdung or "alienating distanciation" as the very condition of understanding, Ricoeur is able to put forward the concept of the world of the text, which is unfolded by the reader in the act of reading. The world of the text provides the reader a proposed world and hermeneutics becomes the interpretation of this proposed world that is unfolded in front of the text: Ricoeur maintains:

The moment of 'understanding'... is the projection of our ownmost possibilities at the heart of the situations in which we find ourselves... [W] hat must [then] be interpreted in a text is a proposed world that I could inhabit and wherein I could project one of my ownmost possibilities. ${ }^{17}$

Ricoeur's hermeneutics is no longer confined to the limited structure of the text; it includes the proposed world that the reader could possibly inhabit. This inclusion of the world of the text and the world of the reader which is brought together in the act of reading is an important springboard: it allows one to see the possibility of an ethics in the act of reading, and even in the act of listening to a life narrated. ${ }^{18}$

At this juncture, it is most beneficial to see the relation of ethics and narrated life. The basic presupposition of Ricoeur is that "life has something to do with narrative," that is, fiction contributes to making a human life. In "Life in Quest of Narrative," he takes Socrates' dictum "an unexamined life is not worth living" and Aristotle's concept of Muthos or emplotment as possible answer to the aporia of life and narrativity.

Ricoeur explains that muthos or emplotment, which could signify both as fable, in the sense of imaginary story, and plot, in the sense of a well constructed story is not a static structure but an active putting together of heterogeneous elements to create a creative re-presentation of reality:

What Aristotle calls plot is not static structure but an operation, an integrating process, which is completed

${ }^{17}$ Ibid., 86.

18 The uniqueness of Ricoeur's hermeneutics lies precisely in what he calls three-fold mimesis where, following the cue of Aristotle, he multiplied the mimetic activity of the narrative into three. This hermeneutics includes the pre-figured human action, which he calls $\mathrm{M}_{1}$ that is configured in the text, which he calls $\mathrm{M}_{2}$ and finally re-figured in the reader, that is, $\mathrm{M}_{3}$. Ricoeur opines that hermeneutics does not only place $M_{2}$ between $M_{1}$ and $M_{3} ; M_{2}$ is precisely hermeneutics' mediating function: "what is at stake therefore is the concrete process by which the textual configuration mediates between the prefiguration of the practical field and its refiguration though the reception of the work... [T] he reader, [then], is that operator par excellence who takes up through doing something — the act of reading — the unity of traversal from mimesis $s_{1}$ to mimesis 3 , by way of mimesis (italics mine)." Ricoeur, From Text to Action, 53. 
only in the reader or in the spectator, that is to say, in the living receiver of the narrated story. ${ }^{19}$

This creative configuration of various elements from a pre-figured set of elements taken from human action and lived experiences allows one to understand the mimetic activity of narration in a completely differently light. Fictional narrative, or even the narration of a life story is not just a mere repetition and enumeration of serial events: it is a dynamic activity of organizing discordant events — which is multiple - in one "followable" story, which leaves, instead of scattered unorganized succession of happenings both good and bad, and faces, both victors and victims, an innovative configured narrative sedimented in a tradition full of life.

These stories created through the vibrant dynamism of mimesis opens a world that shatters all immediate understanding and first level reference of reality. The narrative, similar to the icon, nay as an icon, is a re-writing of reality. ${ }^{20}$ This statement is made to hold water on the account that the icon is understood as not just a weak shadow of reality as stated in Plato's criticism of writing and painting in Phaedrus ${ }^{21}$ but as an augmentation of reality using a limited and dense set alphabet that reconstructs, indeed, reproduce reality and truth: reality is not reduplication; it is metamorphosed. The metamorphosis of the world leaves nothing behind. It transforms everything especially the reader or listener. The narrative is not, then, a self-contained entity. By opening a horizon of possible world of experience, the world of the text allows itself to be appropriated by the reader, an event that happens in the act of reading. Here, the reader unfolds the world of the text giving him the capacity to refigure his own life, thereby, rendering a life now enlarged by fusing its horizons and possibilities with the imaginative variations that the text offers him to inhabit. Ricoeur's hermeneutics is completed in the reception of the reader or listener of the narrative: it is no longer just a means to understand the world and other men; more than anything, narrativity renders man an understanding of himself.

The relation of narrative to life becomes, now, more apparent. Fiction, in so far as it opens a horizon of possibilities for the reader makes the

19 Paul Ricoeur, "Life in Quest of a Narrative," in On Paul Ricoeur: Narrative and Interpretation, ed. by David Wood (New York: Routledge), 21.

20 Inspired by François Dagonet's reconceptualization of eikon, Ricoeur uses the notion of iconicity as the possible rejoinder for the criticism brought forth by Plato against writing. "The question here is whether the theory of the eikon which is held to be a mere shadow of reality, is not presupposition of any critique addressed to any mediation through exterior marks." To which he replied, thus: "Iconicity is the re-writing of reality. Writing, in the limited sense of the word, is a particular case of iconicity. The inscription of discourse is the transcription of the world, and transcription is not reduplication but metamorphosis." Paul Ricoeur, "Speaking and Writing," in Interpretation Theory: Discourse and the Surplus of Meaning (Texas: The Texas Christian University Press, 1976), 40-42.

21 Plato, Phaedrus, in The Collected Dialogues of Plato Including the Letters, ed. by Edith Hamilton and Huntington Cairns, trans. by R. Hackforth (New Jersey: Princeton University Press, 1961), 275 a-e. 
narrative a lot closer to ethical life than theoretical knowledge. Fiction gives the reader "thought experiments" and "lessons" that he can approve or disapprove and these "thought experiments" and "lessons" are given to the reader as a followable configured imitation of reality. Human life moves in the same way. It is constantly pervaded by the incessant movement of human acting and suffering, a movement mediated by symbols that allow action to be recounted in the first place:

Before they are submitted to interpretation, symbols are the internal interpreters of action. In this way symbolism gives an initial readability to action. It makes action a quasi-text for which symbols provide the rules of signification in terms of which a given conduct can be interpreted. ${ }^{22}$

Human acting and suffering which is mediated by symbols allows one to see the "pre-narrative quality of life" that demands to be told, to be narrated. Human life prior to narration is just a biological life, a mere succession of discordant events that needs to be put together through emplotment, and mere series of entanglements that need to be unraveled to make sense of what is otherwise scattered existence and broken humanity. ${ }^{23}$

While Ricoeur says "we tell stories because in the last analysis human lives need and merit being narrated," 24 narration is not only done so that one can tell the story of both the victors and the victim; a life is narrated precisely because human life will only make sense if the discordance brought about by the unstable human time is tempered and allowed to assume an concordant identity if only for a little while. The subjectivity that emanates from the dialectic of time and narrative, of concordance and discordance is a subjectivity that is created by the dynamic composition of the narrative. ${ }^{25}$ This self is no longer the absolute idea clara et distincta of Descartes or the distentio animi of Augustine. This self, though broken and unfinished, faulted and hurt is

22 Ricoeur, "Life in Quest of Narrative," 29.

${ }^{23}$ By putting Aristotle's concept of dynamic plot alongside Augustine's definition of time, Ricoeur is able to posit his notion of discordant concordance: "One could say that in Augustine discordance wins out over discordance: whence the misery of human condition. And that in Aristotle, concordance wins out over discordance, whence the inestimable value of narrative for putting our temporal existence in order." Ibid., 31.

24 Paul Ricoeur, Time and Narrative, I, 75.

25 While it is true that human life is mediated continuously by the stories that are told us, it maintains if pre-narrated quality unless it is mediated by the narrative. Ricoeur, to prove this point gives two examples. The first one is the patient who tells the psychoanalyst "scattered fragments of lived stories, dreams, primal scenes conflictual episodes" which is pieced together by the psychoanalyst to build a narrative, a story more bearable for the patient to make his own. These unrecounted stories are put together and made into a narrative that could comprise the patient's personal identity. The second example that Ricoeur gives is the judge who tries to unravel the entanglement of the defendant with other stories told about the case. By emplotment, the judge is able to make sense of the discordant pieces of stories told by different people, a piecing together of scattered tales to build a narrative that is believable and plausible. Ricoeur, "Life in Quest of Narrative," 30. 


\section{6}

BROKENNESS OF DEATH

rendered capable of refiguring his life in accordance to his ownmost possibilities and the ethical proposal opened up by the text before him and the stories of others that he is entangled in. This unfixed ego may not be the author of his life but he is capable of taking over his pain and capable of forgiving precisely because he can narrate his life otherwise. Indeed, at the face of death, we are shown our shatteredness, but through the creative power of narrativity, we are made aware of the possibility of a happy life, unoppressed by sad memory, freed by the love of the ones who are no longer with us, and saved by the hope of that we will be with them someday.

\section{Epilogue: The Yes to Necessity and Transcendental Hope}

Virulent, indeed, are the dualism in man and reflection allows us to see these dualism in vivid obscenity. Death perhaps is the most pervasive of all instances that shatters our seemingly continuous well-protected lives. One can only imagine the pain that the parents must have felt at the moment the news of their son's death arrived, or the brother, sister and yaya who witnessed how a vibrant life has turned to death's darkness, or the driver who held the child in his arms encouraging him to be strong and given the child's last breath as a response, or the mother who responded to the cries of help but realized that no amount of speed can rival the horse of the Erlkönig. Their pains are given to us not in full; the pains are only heard in the words that they offered in the eulogies and yet, we are hurt still and the words are poignant and we realize that we too are affected by the silence that ensues from the unresponsive body of the beloved dead.

In all these moments of brokenness, our freedom calls us to affirm life despite its limitations and despite the fragility of our bodies. But the consent that we are called to do is not the meretricious human surrender to life's meaninglessness and humanity's absurdities. The consent that is called for is that which is not naive of human suffering and limitation. On the contrary, our freedom has to say yes to a life informed of human fragility and faultedness. But the yes is not the final statement: while we admire the world that allows us, though limited and incomplete, a freedom, whereby we are made capable human beings, that is, capable of acting, telling our stories and stories of others and forgiving, we are still invited to await something else. Ricoeur intimates:

[A]dmiration is possible because the world is an analogy of Transcendence. Admiration sings of the day, reaches the visible miracle, hope transcends in the night. Admiration says, the world is good, it is possible home of freedom; I consent as much as possible, but hope to be delivered of the terrible and at the end of time to enjoy a new body and a new nature granted to freedom. ${ }^{26}$

\footnotetext{
${ }^{26}$ Ricoeur, Freedom and Nature: The Voluntary and the Involuntary, 480.
} 
Both hope and admiration is needed for a happy life in an existence that is not whole from the very start. Death which renders our incompleteness in its most resplendent is given a certain sense of meaning through the manifestation of consent in the courage to narrate a life which is no longer with us. In this act of narration, we do not only memorialize a loved one's life; we also refigure our lives and through the life lived by and told of a loved one, we enlarge ourselves and make our hearts burn in happy acquiescence and forgiveness. And yet, this consent is maintained by the hope of transcendence that drains the sorrow of existence in the bliss of infinity. We resign "everything infinitely, and then [take] everything back on the strength of the absurd." ${ }^{27}$ Life here becomes a hopeful and joyful Yes in the sadness of our finitude. ${ }^{28}$

The Graduate School, University of Santo Tomas, Philippines

\section{References}

Augustine, The Confessions of St. Augustine, trans. by John K. Ryan (New York: Image Book Doubleday, 1960).

Garcia, Leovino, "Hermeneutics: Doing Philosophy with the Social Sciences, Arts and Literature," (Unpublished).

Kierkegaard, Soren, Fear and Trembling: Dialectical Lyric by Johannes de silentio, trans. by Alastair Hannay (London: Peguin Books, 2003).

Marcel, Gabriel, "Primary and Secondary Reflection: The Existential Fulcrum" in Philosophy of Man: Selected Readings, ed. by Manuel B. Dy, Jr. (Makati City: Goodwill Trading Co., Inc., 1986).

Plato, Phaedrus in The Collected Dialogues of Plato Including the Letters, ed. Edith Hamilton and Huntington Cairns, trans. by R. Hackforth (New Jersey: Princeton University Press, 1961).

Ricoeur, Paul, Fallible Man: The Philosophy of the Will, trans. by Charles Kelbley (Chicago: Henry Regnery Company, 1965). , Freedom and Nature: The Voluntary and the Involuntary, trans. by

Erazim V. Kohak (USA: Northwestern University Press, 1966). , "Life in Quest of a Narrative," in On Paul Ricoeur: Narrative and Interpretation, ed. David Wood (New York: Routledge, 1991). "The Task of Hermeneutics," in From Text to Action (Evanston Illinois: Northwestern University Press, 1991). "Time and Narrative: Threefold Mimesis," in Time and Narrative, I (Chicago: University of Chicago Press, 1990)

\footnotetext{
${ }^{27}$ Soren Kierkegaard, Fear and Trembling: Dialectical Lyric by Johannes de silentio, trans. by Alastair Hannay (London: Peguin Books, 2003), 70.

28 This statement is inspired by and "playfully" appropriated from Ricoeur's definition of man in his Fallible Man: "Man is the Joy of the Yes in the sadness of the finite." See Paul Ricoeur, Fallible Man: The Philosophy of the Will, trans. by Charles Kelbley (Chicago: Henry Regnery Company, 1965), 215.
} 


\section{BROKENNESS OF DEATH}

, "Speaking and Writing," Interpretation Theory: Discourse and the Surplus of Meaning (Texas: The Texas Christian University Press, 1976). 